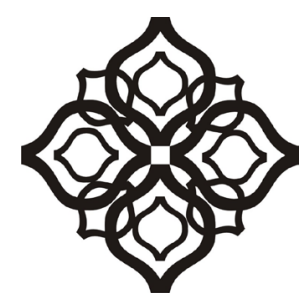

Shirkah

Journal of Economics and Business 


\section{Shirkah}

Journal of Economics and Business

Vol. 4, No. 1, January-April 2019

ISSN: 2503-4235 (p); 2503-4243 (e)

\section{Editor in Chief}

Fitri Wulandari

\section{Managing Editor}

Jasanta Peranginangin

\section{Editorial Boards}

Abdul Azim Islahi, Islamic Economics Institute, King Abdulaziz University, Saudi Arabia Abu Umar Faruq Ahmad, UBD School of Business and Economics Universiti, Brunei Darussalam Cedomir Nestorovic, ESSEC Business School Asia Pacific, Singapore

Fitri Wulandari, Faculty of Islamic Economics and Business, IAIN Surakarta, Indonesia Johan Fischer,

Department of Social Sciences and Business Roskilde Universitetscenter, Denmark Muhamed Zulkhibri, Islamic Research and Training Institute, Islamic Development Bank, Saudi Arabia M. Kabir Hassan,

Department of Economics and Finance, University of New Orleans, United States Musa Asy'arie,

Faculty of Islamic Economics and Business, IAIN Surakarta, Indonesia Nunung Nurul Hidayah, Aston Business School, Aston University, Birmingham, United Kingdom Saim Kayadibi,

Department of Economics, Kulliyyah of Economics and Management Science, International Islamic University Malaysia, Malaysia 
Shaikh M Ghazanfar,

Departement of Economics, University of Idaho, Russian Federation

Sigit S. Wibowo,

Department of Management, Faculty of Economics and Business, Universitas Indonesia, Indonesia

Vihang R. Errunza,

Desmarais Global Finance Research Centre, Desautels Faculty and Management, McGill University, Canada

\section{Assistant to Editor \\ M. Endy Saputro \\ M. Zainal Anwar}

Shirkah Journal of Economics and Business is a peer-reviewed journal published three times a year (January-April, May-August and September-December) by Faculty of Islamic Economics and Business, Institut Agama Islam Negeri (IAIN) Surakarta Central Java, Indonesia. The main objective of Shirkah is to offer an academic space of exchange ideas and initiate the increase number of qualified article produced by postgraduate students, practitioners and academicians.

\section{Editorial Office}

Ruang Jurnal Shirkah

Lantai Dasar, Sayap Barat, Fakultas Ekonomi dan Bisnis Islam, IAIN Surakarta

Jln. Pandawa No. 1, Kartasura, Sukoharjo, Jawa Tengah Kode Pos. 57168

Phone (+62271) 781516 Fax: (+62271)782336

E-mail: shirkahjournal@iainsurakarta.ac.id; shirkahiainsurakarta@gmail.com

Website: http://shirkah.or.id/ 


\section{Shirkah}

Journal of Economics and Business

Vol. 4, No. 1, January-April 2019

ISSN: 2503-4235 (p); 2503-4243 (e)

\section{Table of Contents}

\section{Articles}

Datien Eriska Utami

Identifying Financial and Non-Financial Factors as

the Determinant of Sukuk Rating in Indonesia

JM Muslimin

Halal Product Guarantee in

Indonesia Regulation and Social Inclusion

Isnan Indriati

Muh. Rudi Nugroho

Kuznet's Hypothesis and Ibn Khaldun's Socio-Economic Dimensions

Lucky Nugroho

Ahmad Badawi

Nurul Hidayah

Indonesia Islamic Bank Profitability 2010-2017

Aam Slamet Rusydiana

Lina Marlina

Lina Nugraha Rani

Malmquist Productivity Index on Islamic Economics and

Finance Research

Ahmad Farras Adibuddin

Doddy Setiawan

Bambang Sutopo

The Recent Development of Islamic Economic Studies in Indonesia 


\title{
Malmquist Productivity Index on Islamic Economics and Finance Research
}

\author{
Aam Slamet Rusydiana \\ Sharia Economic Applied Research \& Training (SMART) Indonesia \\ aamsmart@gmail.com \\ Lina Marlina \\ Islamic Economics Department of Universitas Siliwangi Tasikmalaya Indonesia \\ linamarlina@unsil.ac.id \\ Lina Nugraha Rani \\ Faculty of Economic and Business, Airlangga University Indonesia \\ linanugraha@feb.unair.ac.id
}

\begin{abstract}
This study proposes to review the implementation of Malmquist Productivity Index (MPI) in such research publications on the theme of Islamic economics and finance. It employs descriptive statistical analysis based on selected 102 article publications. The entire sample publications have published from 2006 to 2019. The results show that research using the MPI method has still been dominated by Islamic banks issues (73\%) followed by Islamic insurance or takaful issue (12\%), then zakat (8\%), and Islamic microfinance issue (4\%). The rest are issues about halal industry, waqf and Islamic REIT. Malaysia, Indonesia and Pakistan are the 3 countries with the most study areas compared to other countries. In addition, many MPI applications are implemented along with the use of DEA methods for measuring efficiency. The most approach used in 102 studies is the production and intermediation approach.
\end{abstract}

Keywords: Malmquist Index, Productivity, Islamic Economics and Finance

\section{Introduction}

The Malmquist Index or often called the Malmquist Productivity Index (MPI) is part of the Data Envelopment Analysis (DEA) method that specifically looks at the productivity level of each business unit, so 
that changes in the level of efficiency and technology based on the inputs and outputs can be analysed. The Malmquist productivity index has also been utilized to analyze changes in intertemporal performance. The Malmquist Index was first created by Sten Malmquist in 1953 to measure productivity. In its development, the Malmquist Index was advanced by Caves et al. (1982). This method can decompose the level of productivity into changes in technical efficiency and technological change. In addition, the strength of the Malmquist Index method compared to others is that it does not require the assumptions of corporate behavior as applicable in the DEA method such as minimizing costs or maximizing profits.

The Malmquist index method is one of the indices most often used in research measuring the level of productivity of a business unit (Decision Making Unit / DMU), especially the banking industry. Other productivity indexes that are used less frequently include: the Laspeyres Index, the Pasche Index, the Fisher Index and the Tornqvist Index. The Malmquist Index has been represented by the value of the change in total factor productivity or TFP change. As mentioned above, the majority of applications of the DEA and MPI methods are in the banking and financial industries, including Islamic banking. Islamic finance in Indonesia only appeared around 1992, pioneered by Bank Muamalat Indonesia. After that, the Sharia Commercial Bank, Sharia Business Unit, Sharia Rural Bank (BPRS), Sharia Cooperative, Sharia Insurance, Sharia Pawnshop, Waqf, and other Sharia Financial Institutions (LKS) began to develop.

According to Nurfalah et al. (2018), Islamic banking is relatively more stable compared to conventional banking in the face of both internal and external shock. This is an interesting finding that needs to be proven through various researches in the future. Currently the Islamic financial economy is experiencing euphoria, both in developing countries, or even in developed countries. The financial industry and other forms of Islamic 
economic institutions are growing throughout the universe, from the Middle East, the Asian region to Western countries such as the United Kingdom. In Indonesia, the Islamic economy has largely turned into a sharia financial industry, especially sharia banks which are also the bestselling entity "for sale" after the 1997 monetary crisis (Rusydiana et al, 2009).

This study portrays the application of research using the Malmquist Index productivity measurement method in the theme of Islamic economics and finance. Such problems in this research as; first, what are the topics of study of Islamic economics and finance that apply the MPI method. Second, in a research methodology approach, what is the composition of research related to the MPI method in Islamic economics and finance in general. Then how many the percentage of the number of publications, types of research, research approaches, to the object of study the application of the MPI method in Islamic economics and finance over the past 14 years (2006-2019).

\section{Situating The Malmquist Index}

The concept of productivity is basically a relationship between output and input in a production process. Productivity can be measured partially or totally. Partial productivity is the relationship between output and one input. Examples of partial productivity that are commonly used are labor productivity which shows the average output per labor, as well as capital productivity which illustrates the average output per capital. Total productivity or commonly called Total Factor Productivity (TFP) measures the relationship between outputs and several inputs together. The relationship has been expressed in the ratio of the output index to the aggregate input index. If the ratio increases, more output can be produced using a certain number of inputs, or a number of outputs can be 
produced using fewer inputs. In measuring productivity, the most widely used method is total factor productivity (TFP). This method is used to overcome the weaknesses in calculating efficiency of more than one input and one output. TFP has been measured using index numbers that can measure changes in prices and quantities over time. In addition, TFP also measures comparisons and differences between entities.

The TFP index ab measures the change in the value of selected $\mathrm{N}$ outputs from the period "a" to " $b$ " where $p$ represents the output price. Indexes that are often used to measure TFP are Malmquist Index, Laspeyres Index, Pasche Index, Fisher Index and Tornqvist Index. In this study, what will be used to calculate the level of productivity (TFP) is the Malmquist Index. The Malmquist Index was first created by Sten Malmquist in 1953 to measure productivity. But in its development, the Malmquist Index was introduced by Caves et.al (1982). There are two things that are calculated in the Malmquist index measurement, namely the catch-up effect and the frontier shift effect. The catch-up effect measures the rate of change in relative efficiency from period 1 to period 2. Meanwhile the frontier shift effect measures the rate of technological change which is a combination of inputs and outputs from period 1 to period 2. The frontier shift effect is often referred to as the innovation effect.

The Malmquist Index is a bilateral index used to compare production technologies of two economic elements. The Malmquist Index is based on the concept of a production function that measures the maximum production function within a predetermined input limit. In its calculation, this index consists of several results, namely: efficiency change, technological change, pure efficiency change, economic scale change and TFP change. The Malmquist Index has several beneficial characteristics. First, this index is a non-parametric method so it does not require the specification of the production function form. Second, the Malmquist 
index does not require assumptions of the economic behavior of the production unit such as cost minimization or profit maximization, so it is very useful if the goals of the producers are different or unknown. Third, the calculation of this index does not require price data which are often not available. Fourth, the Malmquist productivity index can be broken down into two components, namely changes in efficiency and changes in technology. According to Avenzora (2008) this is very useful because the analysis can be done more specifically based on components.

In the first generation model developed by Caves et.al (1982), there are 2 (two) Malmquist productivity index models (Bjurek, 1996). First is 'Malmquist input quantity index' and second is 'Malmquist output quantity index'. Malmquist input quantity index for a unit of production, at the time of observation $t$ and $t+1$, for technology reference in periods $\mathrm{k}, \mathrm{k}=\mathrm{t}$ and $\mathrm{t}+1$. The Malmquist input quantity index only measures changes in the input quantity observed between times $t$ and $t+1$, where:

$$
M I_{k}\left(y_{k}, x_{t}, x_{t+1}\right)=\frac{E_{k}^{I}\left(y_{k}, x_{t}\right)}{E_{k}^{I}\left(y_{k}, x_{t+1}\right)}, k=t, t+1
$$

Next, for the Malmquist quantity output index for a unit of production, at the time of observation $t$ and $t+1$, for technology reference in periods $\mathrm{k}, \mathrm{k}=\mathrm{t}$ and $\mathrm{t}+1$. The Malmquist output quantity index only measures changes in the quantity of output observed between time $t$ and $t+1$, where:

$$
M O_{k}\left(y_{t}, y_{t+1}, x_{k}\right)=\frac{E_{k}^{O}\left(y_{t+1}, x_{k}\right)}{E_{k}^{O}\left(y_{t}, x_{k}\right)}, k=t, t+1
$$

Bjurek (1996) introduced a new definition of the Malmquist productivity index for production units between $t$ and $t+1$ based on the level of technology at time $\mathrm{k}, \mathrm{k}=\mathrm{t}$ and $\mathrm{k}=\mathrm{t}+1$, following the tradition of 
most productivity indices. Adjusting to the Tornqvist productivity index, the index constructed is a ratio between an output index and an input index:

$\operatorname{MTFP}_{k}=\frac{M O_{k}\left(y_{t}, y_{t+1}, x_{k}\right)}{M I_{k}\left(y_{k}, x_{t}, x_{t+1}\right)}=\frac{E_{k}^{O}\left(y_{t+1}, x_{k}\right) / E_{k}^{O}\left(y_{t}, x_{k}\right)}{E_{k}^{I}\left(y_{k}, x_{t}\right) / E_{k}^{I}\left(y_{k}, x_{t+1}\right)}, k=t, t+1$

The equation above illustrates the ratio between the output index and the Malmquist input index. If the productivity index value is greater than number 1 , then there has been an increase in productivity. If the index value is less than 1 , the level of productivity decreases, while if it is equal to 1 , the level of productivity does not change.

\section{Research Method}

This study utilizes data in the form of research journals and other research publications for the period 2006-2019 that have been published regarding the application of the Malmquist Productivity Index method in Islamic economic and financial research. These journals had been obtained or accessed online from published journals sites. The methodology used in this study is a qualitative method approach with descriptive statistics of literature studies of 102 publications related to the application of the Malmquist Productivity Index method in the area of Islamic economics and finance. Data collection techniques are carried out by triangulation (combined), data analysis is inductive/ qualitative, and qualitative research results emphasize more on the meaning of generalization (Sugiyono, 2008).

Qualitative research is descriptive. The data analyzed does not to accept or reject the hypothesis (if any). The results of the analysis are in the form of descriptions of observed symptoms and do not have to be numbers or coefficients between variables (Subana and Sudrajat: 2005). According to Wijaya (2013), descriptive statistics are a field of statistical 
science that studies ways of collecting, compiling and presenting research data summaries. The data must be summarized well and regularly, both in the form of tables, diagrams or graphic presentations, as a basis for various decision making (Wijaya, 2013). This research was processed using Ms. Excel.

This study uses a purposive non probability sampling method. This sample has grouped into a decision sample (judgment) that selects sample members according to certain criteria on the basis of past records or research objectives to be achieved, and quota samples are selected based on quotas or certain categories, which describe the dimensions of dimension (proportion) of population (Wijaya, 2013). The criteria referred to in this study are 102 publications related to the application of the Malmquist Productivity Index method in the theme of Islamic economics and finance from 2006-2019.

\section{Result and Disscussion}

Based on Appendix 1, the sources of the most widely discussed MPI publications is International Journal of Islamic and Middle Eastern Finance and Management with 3 papers. Then, the most widely discussed MPI publications are the Journal of Islamic Banking and Finance, Service Industries Journal, Applied Economics, Journal of Development Economics, International Journal of Productivity and Performance Management, Economic Modelling, Education and Humanities Research, Review of Islamic Economics, Islamic Economic Studies, International Journal of Business and Society, Humanomics, Journal of Asian Finance, Economics and Business, Indonesian Sharia Economic Journal, Journal of Islamic Economics, Banking and Finance, and Journal of Islamic Business and Management. Where, each publisher's name amounts to two papers discussing MPI. Meanwhile, the most conferences that published papers on MPI were the 1st International 
Conference on Islamic Economics, Business, and Philanthropy (ICIEBP 2017) with a total of two papers. In addition, in this study there were also one working paper.

This study reviewed 102 studies with publishing from 2006 to 2019. During this period, research on the three-year MPI with the most publications occurred in 2017 to 2019. The number of papers in the three years were 14,12, and 10 papers, respectively. During 2006 to 2019, there was an increase and a decrease. In 2006 there was only 1 paper and in 2019 there were 10. This shows that the development of the MPI analysis model to see the efficiency of a company is increasing. The following is a table of years of publication and the number of papers each year.

Table 1. Classification of Publications by Year

\begin{tabular}{|c|c|c|}
\hline No. & Year of Publication & Number of Articles \\
\hline 1 & 2019 & 10 \\
\hline 2 & 2018 & 12 \\
\hline 3 & 2017 & 14 \\
\hline 4 & 2016 & 7 \\
\hline 5 & 2015 & 9 \\
\hline 6 & 2014 & 7 \\
\hline 7 & 2013 & 8 \\
\hline 8 & 2012 & 7 \\
\hline 9 & 2011 & 8 \\
\hline 10 & 2010 & 7 \\
\hline 11 & 2009 & 2 \\
\hline 12 & 2008 & 2 \\
\hline 13 & 2007 & 8 \\
\hline 14 & 2006 & 1 \\
\hline Total & & 102 \\
\hline
\end{tabular}


In the 102 papers we reviewed, we classified according to the names of the authors who often did research on MPI. The names of writers who often conduct research on MPI are Fadzlan Sufian and Aam Slamet Rusysiana, with 6 papers each. Then, Mariani Abdul Majid also conducted research on MPI by making 5 papers. In addition to the researchers already mentioned, researchers who conducted research using MPI for more than 2 papers included Fakarudin Kamarudin and Zulkifar Bagus Pambuko, each with 4 papers, and who wrote three papers including M. Kabir Hassan, Aslam Mia, Nazratul Aina MA, Norma Md Saad, and Md Azizur Rahman. The distribution list of researchers using the most MPI methods in the paper written can be explained in the following table.

Table 2. Authors of MPI research

\begin{tabular}{|c|l|c|}
\hline No & \multicolumn{1}{|c|}{ Writer } & $\begin{array}{c}\text { Number of } \\
\text { Papers }\end{array}$ \\
\hline 1 & Fadzlan Sufian & 6 \\
\hline 2 & Aam Slamet Rusydiana & 6 \\
\hline 3 & Mariani Abdul-Majid & 5 \\
\hline 4 & Fakarudin Kamarudin & 4 \\
\hline 5 & Zulkifar Bagus Pambuko & 4 \\
\hline 6 & M Kabir Hassan & 3 \\
\hline 7 & Aslam Mia & 3 \\
\hline 8 & Nazratul Aina Mohammad Anwar & 3 \\
\hline 9 & Norma Md Saad & 3 \\
\hline 10 & Md Azizur Rahman & 3 \\
\hline
\end{tabular}

We next classify the reviewed papers based on the focus of the study on the Islamic financial sector. Studies conducted cover various sectors such as banking, endowments, insurance, zakat, microfinance institutions, etc. In 102 papers, the sector with the most MPI research occurred in the banking sector of 74 papers. The insurance sector is also in great 
demand by researchers with a total of 12 papers. Other sectors that are quite attractive to researchers are zakat totaling 8 papers and microfinance institutions totaling 4 papers. Following is a list of sectors that are the focus of researchers and the number of papers can be seen in Table 4.

Table 3. Classification of Publications by Sector Focus Study

\begin{tabular}{|c|l|c|}
\hline No & \multicolumn{1}{|c|}{ Focus } & Number of Papers \\
\hline 1 & Islamic Banking & 74 \\
\hline 2 & Islamic Insurance (Takaful) & 12 \\
\hline 3 & Zakat & 8 \\
\hline 4 & Islamic Microfinance & 4 \\
\hline 5 & Waqf & 2 \\
\hline 6 & Halal Industry & 1 \\
\hline 7 & REIT Industry & 1 \\
\hline & Total & 102 \\
\hline
\end{tabular}

We then classify reviewed papers based on studies conducted in certain countries. Studies conducted in various countries and comparative analysis between countries are also found in the literature that we review. In 102 papers, case studies in the country with the most MPI research occurred in Malaysia as many as 34 papers, and the second and third most occurred in Indonesia and Pakistan, namely 26 and 13 papers. Developing countries get the greatest attention of researchers, namely in Malaysia and Indonesia. Whereas in European countries each is less desirable by researchers. Following is a list of countries and the number of papers can be seen in Table 5 .

Table 4. Classification of Publications Based on Country Studies

\begin{tabular}{|c|l|c|}
\hline No & \multicolumn{1}{|c|}{ Country } & Number \\
\hline 1 & Malaysia & 34 \\
\hline 2 & Indonesia & 26 \\
\hline
\end{tabular}




\begin{tabular}{|c|l|c|}
\hline 3 & Pakistan & 13 \\
\hline 4 & Bangladesh & 9 \\
\hline 5 & Turkey & 7 \\
\hline 6 & Qatar & 4 \\
\hline 7 & UAE & 4 \\
\hline 8 & Brunei Darussalam & 3 \\
\hline 9 & UK & 1 \\
\hline 10 & Others & 16 \\
\hline
\end{tabular}

Then we classify research based on various research methodologies. We identified four categories of methodologies used by researchers in our paper that covered empirical, conceptual, and cross-sectional exploration methods. Conceptual studies are based on certain concepts, models and approaches (parametric and non-parametric) and techniques with different approaches. Empirical studies formally estimate and evaluate efficiency and changes in productivity using a database. Studies based on surveys are defined as exploratory cross-sectional studies. Table 5 illustrates the distribution of the methodology in the study we reviewed.

Table 5. Classification of Publications Based on Methodology

\begin{tabular}{|c|l|c|}
\hline No & \multicolumn{1}{|c|}{ Methodology } & Number of Papers \\
\hline 1 & Empirical & 78 \\
\hline 2 & Conceptual & 1 \\
\hline 3 & Exploratory cross sectional & 23 \\
\hline & Total & 102 \\
\hline
\end{tabular}

Based on the results in Table 5, most of the studies use the empirical method of evaluating efficiency and productivity using a database of 78 papers. In addition to using empirical methods, exploratory cross section research methods were also used as many as 23 papers. While research using conceptual methods only 1 paper. This conceptual model illustrates 
a step-by-step research approach to evaluating and assessing changes in the efficiency and productivity of the Islamic economic sector.

Table 5 shows an overview of the methodology distribution and clarifies that most studies are empirical. On the basis of the distribution of literature and studies reviewed, we designed a conceptual flow chart to represent each and every step needed in research based on the approach of the type of analytical tool of the efficiency of the Islamic economic sector. The distribution of analytical tool approaches and the number of papers can be seen in Table 6 .

Table 6. Classification of Publications Based on Analysis Tools Approach

\begin{tabular}{|c|l|c|}
\hline No & Frontier approach & Number of Papers \\
\hline 1 & MPI & 47 \\
\hline 2 & MPI and DEA & 53 \\
\hline 3 & MPI and other method & 2 \\
\hline
\end{tabular}

Based on the results in Table 6, the analysis tool approach that is often done by researchers is MPI and DEA as many as 53 studies, while for those who only use the MPI approach as many as 47 studies. In addition, there are 2 researchers who used other analysis tools besides MPI and DEA, namely Frontier shift effect and Panzar Rosse (PR) analysis tools. DEA is a non-parametric approach to evaluating the efficiency of an Islamic economic sector, while the Malmquist Productivity Index (MPI) is one of the most popular methods used to deal with changes in total factor productivity (TFP).

Approach for selecting input-output combinations. The choice of input-output combination is a very complex problem, because each DMU may have an " $n$ " number of inputs and outputs. From the literature we have identified the following approaches for variable selection including the production approach, intermediation approach, value added approach, 
and other approaches. The following is a list of approaches to input-output combination and number of studies.

Table 7. Classification of Publications Based on the Input-Output

Combination Approach

\begin{tabular}{|c|l|c|}
\hline No & \multicolumn{1}{|c|}{ Approach } & $\begin{array}{c}\text { Number of } \\
\text { Papers }\end{array}$ \\
\hline 1 & Production approarch & 47 \\
\hline 2 & Intermediation approach & 43 \\
\hline 3 & Value added approach & 4 \\
\hline 4 & Others & 8 \\
\hline
\end{tabular}

The production and intermediation approach is the main approach used in the literature, which consists of 47 papers and 43 papers, respectively. The production approach assumes the sector as a unit of production, which produces loans, deposits and other financial services using inputs such as labor (number of employees, employee costs) and capital (fixed assets and other assets). While the intermediation approach assumes the Islamic economic financial sector as an intermediary for financial service products. The production approach treats deposits as output variables while the intermediation approach views deposits as input variables. The value added approach was also undertaken by researchers with a total of 4 papers, and an approach other than three that has mentioned as many as 8 papers used by researchers to look at input-output combinations.

Several studies have tried a two-stage approach to determine the factors that influence efficiency and changes in productivity. In the first stage the researcher assessed the efficiency and changes in productivity and in the next stage the efficiency scores and changes in productivity were regressed on a determining variable which included Islamic financial sector variables, macroeconomic variables, and regulatory variables. The 
following is a list of papers that use various data analyzes as a second step approach.

Table 8. Classification of Literature based on The Second Stage Approach

\begin{tabular}{|l|l|c|}
\hline No & Second Stage Regression Techniques & $\begin{array}{c}\text { Number of } \\
\text { Papers }\end{array}$ \\
\hline 1 & Tobit regression & 9 \\
\hline 2 & Panel data regression & 7 \\
\hline 3 & Simple regression & 3 \\
\hline 4 & Others & 4 \\
\hline
\end{tabular}

Table 8 shows the tobit regression is a technique that is widely used for the second stage approach of 9 papers. Panel data regression is also widely used by researchers namely as many as 7 papers, while using simple regression for the second stage approach of 3 papers. In addition to these three techniques, the researchers also used other techniques for the determinants of a number of 4 papers which included Generalized Least Squares (GLS) regression techniques, Paired dependent t tests, Bootstrap regression, and Multivariate Panel Regression Analysis to assess the impact of determinants on efficiency and changes in the productivity of the banking industry.

\section{Conclusion}

The focus of this research is to find out the extent of the development of the application of the Malmquist Productivity Index method in research primarily related to Islamic economic and financial research in the world. The results show that there is a tendency for an increase in the number of articles on publications on Islamic economics and finance with the application of the MPI method over the study period, especially in the last 3 years. The application of the MPI method in Islamic economic and 
financial research is dominated by discussion of themes related to Islamic banks and Islamic insurance (takaful), furthermore the themes of zakat and Islamic microfinance.

Malaysia, Indonesia and Pakistan are the 3 countries with the most study areas compared to other countries, followed by Bangladesh, Turkey and the GCC. In terms of methodology, many MPI applications are implemented together with the use of DEA methods for measuring efficiency. Meanwhile, research by the independent MPI is relatively less than the first group. Nearly the entire research sample is empirical, not conceptual. The most efficient and productivity measurement approach used in 102 studies with the MPI method is the production and intermediation approach, while the value-added approach, the asset approach and other approaches, are relatively less used. Some MPI studies are continued with the second phase which is parametric. The majority of the two-stage MPI methods use the tobit regression and panel regression models. While other models are simple regression, GLS, and bootstrapped models.

\section{Acknowledgment}

The authors thank to Sofina Mujadiddah from IPB University for the collection and analysis of data. 


\section{References}

Abduh, M., Hasan, S. M., \& Pananjung, A. G. (2013). Efficiency and performance of Islamic banks in Bangladesh. Journal of Islamic Banking and Finance, 30(2), 94-106. Retrieved from http://irep. iium.edu.my/30750/

Abduh, M., Omar, M. A., \& Tarmizi, R. M. (2012). Measuring the Performance of Insurance Industry in Malaysia: Islamic vis-a-vis Convetional Insurance. Journal of Islamic Banking and Finance, 29(4), 40-49.

Abdul-Majid, M. (2010). Productivity Growth of Malaysian Banks: Foreign-Owned Islamic Banks and Islamic Bank Subsidiaries. Prosiding Perkem, 5(1), 225-235. https://doi.org/10.4197/Islec.24-2.5

Abdul-Majid, M., \& Hassan, M. K. (2011). The impact of foreignowned islamic banks and islamic bank subsidiaries on the efficiency and productivity change of Malaysian banks. Journal of King Abdulaziz University, Islamic Economics, 24(2), 149-176. https://doi. org/10.4197/Islec.24-2.5

Abdul-Majid, M., Saal, D. S., \& Battisti, G. (2011a). Efficiency and total factor productivity change of Malaysian commercial banks. Service Industries Journal, 31(13), 2117-2143. https://doi.org/10.1080/026 42069.2010 .503882

Abdul-Majid, M., Saal, D. S., \& Battisti, G. (2011b). The impact of islamic banking on the cost efficiency and productivity change of Malaysian commercial banks. Applied Economics, 43(16), 2033-2054. https:// doi.org/10.1080/00036840902984381

Abdul-Wahab, A. H., \& Haron, R. (2017). Efficiency of Qatari banking industry: an empirical investigation. International Journal of Bank Marketing, 35(2), 298-318. https://doi.org/10.1108/IJBM-07-20160090 
Abu-alkheil, A. M., Burghof, H.-P., \& Khan, W. A. (2012). Comparison Of Efficiency And Productivity Changes Of Islamic And Conventional Banks: Evidence From Europe And Muslim-Majority Countries? The Journal of Applied Business Research, 28(6), 1385-1412.

Ada, A. A. (2014). Efficiency Analysis in Islamic Banks : A Study for Malaysia and Turkey. BDDK Bankacılık ve Finansal Piyasalar, 8(1), 9-33.

Afiatun, P., \& Wiryono, S. (2002). Efficiency and Productivity of Indonesian Islamic Banking. Journal of Technology Management, 9(3).

Ahmad, R., Hussain, A., Umer, M., \& Parveen, K. (2017). Efficiency of Microfinance providers in Pakistan: An Empirical Investigation. Review of Economics and Development Studies, 3(2), 147-158. https:// doi.org/10.26710/reads.v3i2.173

Aisyah, S., \& Hosen, M. N. (2018). Total Factor Productivity and Efficiency Analysis on Islamic Banks in Indonesia. Jurnal Keuangan Dan Perbankan, 22(1), 137-147. https://doi.org/10.26905/jkdp. v22i1.1333

Ajija, S. R., Yasin, M. Z., \& Albra, R. (2017). Indonesian Banking Efficiency: Transmission to the Financial Stability Confronting ASEAN Economic Community. Jurnal Ekonomi Pembangunan: Kajian Masalah Ekonomi Dan Pembangunan, 18(2), 183. https://doi. org/10.23917/jep.v18i2.5095

Akhtar,M.H.(2010a).AreSaudibanksproductiveandefficient? International Journal of Islamic and Middle Eastern Finance and Management, 3(2), 95-112. https://doi.org/10.1108/17538391011054354

Akhtar,M.H.(2010b). Technical efficiency and productivity growth of Saudi banks: A data envelopment analysis approach. Global Business Review, 11(2), 119-133. https://doi.org/10.1177/097215091001100201

Al-Amri,K.,Gattoufi,S., \&Al-Muharrami,S.(2012).Analyzing thetechnical efficiency of insurance companies in GCC. Journal of Risk Finance, 13(4), 362-380. https://doi.org/10.1108/15265941211254471 
Al-jarrah, I. M. (2012). Assessing the Productivity Change in the Banking Sector of Jordan. Middle Eastern Finance and Economics, 17(17), 98107. Retrieved from http://www.middleeasterneconomicsandfinance. com

Al-Muharrami, S. (2007). The causes of productivity change in GCC banking industry. International Journal of Productivity and Performance Management, 56(8), 731-743. https://doi. org/10.1108/17410400710833029

Alendejani, M., \& Asutay, M. (2017). Determining the Efficiency of Islamic and Conventional Commercial Banks in the GCC: Islamic Finance: Performance and Efficiency (Volume 3), (May 2005), 11-50. https://doi.org/10.2307/j.ctt1df4hbd.4

Alexakis, C., Izzeldin, M., Johnes, J., \& Pappas, V. (2019). Performance and productivity in Islamic and conventional banks: Evidence from the global financial crisis. Economic Modelling, 79, 1-14. https://doi. org/10.1016/j.econmod.2018.09.030

Alpay, S., \& Hassan, M. K. (2007). A Comparative Efficiency Analysis of Interest Free Financial Institutions and Conventional Banks: A Case Study on Turkey.

Ariss, R. T., Rezvanian, R., \& Mehdian, S. M. (2007). Cost Efficiency, Technological Progress and Productivity Growth of Banks in GCC Countries. International Journal of Business, 12(4), 471482,486,488-491. Retrieved from http://search.proquest.com/ docview/198016194?accountid=10297\%5Cnhttp://sfx.cranfield. ac.uk/cranfield?url_ver=Z39.88-2004\&rft_val_fmt=info:ofi/ fmt:kev: $m$ tx:journal\&genre=article \&sid=ProQ:ProQ:abiglobal $\&$ atitle $=$ Cost + Efficiency, + Technological + Progress + and + Pro

Assaf, A. G., \& Barros, C. (2011). Performance analysis of the Gulf hotel industry: A Malmquist index with bias correction. International Journal of Hospitality Management, 30(4), 819-826. https://doi. org/10.1016/j.ijhm.2011.01.002 
Avenzora, Ahmad dan Jossy P. Moeis. (2008). Analisis Produktivitas dan Efisiensi Industri Tekstil dan Produk Tekstil di Indonesia tahun 20022004. Jakarta 2008.

Awdeh, A. (2013). Impact of Financial Deregulation on Bank Productivity : Evidence from a Panel of Arab Banks. Journal of Asian Development Studies, 2(4), 6-22.

Azad, M. A. K., Munisamy, S., Masum, A. K. M., Saona, P., \& Wanke, P. (2017). Bank efficiency in Malaysia: a use of malmquist metafrontier analysis. Eurasian Business Review, 7(2), 287-311. https:// doi.org/10.1007/s40821-016-0054-4

Bahrini, R. (2015). Productivity of MENA Islamic banks: a bootstrapped Malmquist index approach. International Journal of Islamic and Middle Eastern Finance and Management, 8(4), 508-528. https://doi. org/10.1108/mf.2008.00934jaa.001

Bjurek, H. (1996). The Malmquist Total Factor Productivity Index. Scandinavian Journal of Economics,98(2), 303-313.

Boyacioglu, M. A., Sahin, I. E., \& Aktas, R. (2014). a Comparison of the Financial Efficiencies of Commercial Banks and Participation Banks : the Case of. 11th Internasional Academic Conference, 7-26.

Bushara, M. O. A., Aziz, Y. A. M., \& Hussain, A. I. M. (2018). The sources of productivity change in Yemen Islamic banks : An application of Malmquist productivity index. International Journal of Financial Management and Economics, 1(1), 39-45.

Caves, et al. (1982). The Economic Theory of Index Number and The Measurement of Input, Output and Productivity. Econometrica, 50(6), 1393-1414.

Chuweni, N. N., Isik, I., \& Blake, A. (2019). Total Factor Productivity Change in The Reit Industry: The Case of Malaysian Reits During and Post Global Financial Crisis. Journal of the Malaysian Institute of Planners, 17(1), 149-159. 
Defung, F., Salim, R., \& Bloch, H. (2017). Economic liberalization and sources of productivity growth in Indonesian Banks: is it efficiency improvement or technological progress? Applied Economics, 49(33), 3313-3327. https://doi.org/10.1080/00036846.2016.1259748

Djaghballou, C. E., Djaghballou, M., Larbani, M., \& Mohamad, A. (2018). Efficiency and productivity performance of zakat funds in Algeria. International Journal of Islamic and Middle Eastern Finance and Management, 11(3), 474-494. https://doi.org/10.1108/ IMEFM-07-2017-0185

Faruk, O., \& Rahaman, A. (2015). Measuring Efficiency of Conventional Life Insurance Companies in Bangladesh and Takaful Life Insurance Companies in Malaysia : A Non-Parametric Approach. Management Studies and Economic Systems, 2(2), 129-144. https://doi. org/10.12816/0019398

Faruk, U., Disman, D., \& Nugraha, N. (2017). Efficiency and Productivity Growth Analysis of the Islamic Banking in Indonesia: Data Envelopment Analysis and Malmquist Productivity Index Approach. 1st International Conference on Islamic Economics, Business, and Philanthropy (ICIEBP 2017), 213-218. https://doi. org/10.5220/0007079502130218

Firmansyah, I. (2019). Measuring of Islamic Banking Productivity in Indonesia Using Malmquist Index. Education and Humanities Research, 203, 251-254. https://doi.org/10.2991/iclick-18.2019.51

Ganouati, J., \& Essid, H. (2017). The sources of productivity change and efficiency in Islamic banking: Application of Malmquist productivity index. The Central European Review of Economics and Management, 1(4), 35. https://doi.org/10.29015/cerem.555

Hadad, M. D., Hall, M. J. B., Kenjegaliev, K. A., Santoso, W., \& Simper, R. (2011). Productivity changes and risk management in Indonesian banking: A Malmquist analysis. Applied Financial Economics, 21(12), 847-861. https://doi.org/10.1080/09603107.2010.537636 
Hadi, F. S. A., \& Saad, N. M. (2010). An analysis on the efficiency of the Malaysian Islamic banking industry: domestic vs. foreign. Review of Islamic Economics, 14(1), 27-47.

Hassan, M. K. (2006). The X-Efficiency In Islamic Banks. Islamic Economic Studies, 13(2), 50-78.

Isik, I., Kulali, I., \& Agcayazi-Yilmaz, B. (2016). Total Factor Productivity Change in the Middle East Banking. International Journal of Research in Business and Social Science (2147-4478), 5(3), 1-29. https://doi. org/10.20525/ijrbs.v5i3.296

Islam, D. J., Rahman, M. A., \& Bhuiyan, M. Z. H. (2013). Measures of efficiency in the takaful industry of Bangladesh, A non-parametric approach.pdf. Islamic Management and Business, 5(11), 163-173.

Ismail, M., Sulaiman, S., \& Rahim, A. H. (2008). Impact of Merger on Efficiency and Productivity: A Case Study of Commercial Banks in Malaysia. Social and Management Research Journal, 5(1), 77-90. https://doi.org/10.1017/CBO9781107415324.004

Jahan, N. (2019). Productivity Analysis of Commercial Banks of Bangladesh: A Malmquist Productivity Index Approach. International Journal of Economics and Financial Issues, 9(1), 108-115.

Johnes, J., Izzeldin, M., \& Pappas, V. (2015). Efficiency and productivity change in Islamic and conventional banks: Evidence from the Gulf Cooperation Council (GCC) countries. 13th International Conference on Data Envelopment Analysis, (April). Retrieved from http://eprints. hud.ac.uk/27824/

Jreisat, A., Al-Barghouthi, S., Qasim, A., \& Nimer, K. (2017). Global financial crisis and productivity changes of banks in UAE: A DEAMPI analysis. International Journal of Business and Society, 18(Special Issue 3), 437-448.

Kamarudin, F., Hue, C. Z., Sufian, F., \& Mohamad Anwar, N. A. (2017). Does productivity of Islamic banks endure progress or regress?: Empirical evidence using data envelopment analysis based 
Malmquist Productivity Index. In Humanomics (Vol. 33). https://doi. org/10.1108/H-08-2016-0059

Kamarudin, F., Rajah, K. T., Ramli, N. A., \& Mohamad Anwar, N. A. (2018). Impact Of Country Governance on Islamic and Conventional Banks' Malmquist Productivity Index. Internasional Conference on Social Science Studies (ICSS 2018), 35-73. https://doi. org/10.1111/j.1467-9515.1987.tb00283.x

Keskin Benli, Y., \& Degirmen, S. (2013). The application of data envelopment analysis based Malmquist total factor productivity index: Empirical evidence in Turkish banking sector. Panoeconomicus, 60(3 SPEC. ISSUE), 139-159. https://doi.org/10.2298/PAN1302139K

Khan, A., \& Noreen, U. (2014). Efficiency Measure of Insurance v/s Takaful Firms Using DEA Approach : A Case of Pakistan. Islamic Economic Studies, 22(1), 139-158. https://doi.org/10.12816/0004133

Khan, M. I., \& Shah, I. A. (2015). Cost Efficiency and Total Factor Productivity of Islamic and Conventional Banks in Pakistan. Research Journal of Finance and Accounting, 6(5), 135-146.

Lee, H. S., Cheng, F. F., Md Nassir, A., \& Ab Razak, N. H. (2019). Impacts of Risk Based Capital Regulation in Malaysian Islamic Insurers (Takaful). Asian Academy of Management Journal of Accounting and Finance, 15(1), 27-59. https://doi.org/10.21315/aamjaf2019.15.1.2

Mahmood, H.Z., Khan, R., Mehmood, B., \& Khan, M. (2014). Efficiency Analysis of Conventional vs . Islamic Microfinance: An Appraisal for Sustainability in Pakistan. International Journal of Empirical Finance Information, 3(4), 192-201.

Masud, M. M., Rana, M. S., Mia, M. A., \& Saifullah, M. K. (2019). How productive are life insurance institutions in Malaysia? A malmquist approach. Journal of Asian Finance, Economics and Business, 6(1), 241-248. https://doi.org/10.13106/jafeb.2019.vol6.no1.241

Md. Azizur Rahman1. (2014). Efficiency Comparison between Life and NonLifetakafuloperators in Bangladesh-A Non Parametric 
Approach $\backslash n$. IOSR Journal of Business and Management (IOSR-JBM), 16(12), 38-49. https://doi.org/10.9790/487X-161233849

Mustafa, S., \& Mehmood, B. (2015). Efficiency Change in Pakistan Commercial Banking Sector: A Pre and Post Digital-Restructuring Analysis. Journal of Emerging Economies and Islamic Research, 3(1), 1-10. Retrieved from http://www.jeeir.com/v2/images/ Vol3No12015/142-317-2-PB.pdf

Noreen, U., \& Ahmad, S. (2016). Cost Efficiency and Total Factor Productivity: An Empirical Analysis of Pakistan's Insurance Sector. The Lahore Journal of Economics, 21(1), 123-150. https://doi. org/10.35536/lje.2016.v21.i1.a5

Norfitriani, S. (2016). Analisis Efisiensi dan Produktivitas Bank Syariah di Indonesia Sebelum dan Sesudah Spin Off. Jurnal Ekonomi Syariah Indonesia, 6(2), 134-143. Retrieved from http://ejournal.almaata. ac.id/index.php/JESI/article/view/430

Nurfalah, I., Rusydiana, A.S., Laila, N., and Cahyono, E.F. 2018. Early warning to banking crises in the dual financial system in Indonesia: The markov switching approach. JKAU: Islamic Economics, 31(2), 133-156.

Omar, M. A., Abd. Majid, M. S., \& Rulindo, R. (2007). Efficiency and Productivity Performance of the National Private Banks in Indonesia. Gadjah Mada International Journal of Business, 9(1), 1. https://doi. org/10.22146/gamaijb.5603

Onour, I. A. (2011). Efficiency of Islamic Banks in Sudan: A nonparametric Approach 1. Journal of Islamic Economics, Banking and Finance, 7(4), 79-92.

Othman, A., Kari, F., \& Hamdan, R. (2013). A Comparative Analysis of the Co-operative, Islamic and Conventional Banks in Malaysia. American Journal of Economics, 3(5C), 184-190. https://doi.org/10.5923/c. economics.201301.31 
Pambuko, Z. B., Usman, N., \& Andriyani, L. (2019). Spin-off and Social Funds' Productivity of Islamic Banking Industry in Indonesia. Education and Humanities Research, 317, 7-10. https://doi. org/10.2991/iconprocs-19.2019.2

Parisi, S. Al. (2017). Tingkat Efisiensi dan Produktivitas Lembaga Zakat di Indonesia. Jurnal Bisnis Dan Manajemen, 7(1), 63-72. https://doi. org/10.15408/ess.v7i1.3687

Paul, S., \& Jreisat, A. (2012). Does Deregulation Improve the Productivity of Banks? Internasional Journal of Financial Economics and Econometrics, 4(1), 61-72.

Pitaloka, J. M., Cholis, N., Islamiyah, A., \& Pambuko, Z. B. (2018). Determinan Produktivitas Sosial Perbankan Syariah di Indonesia: Two-Stage Malmquist Productivity Index. Jurnal Studi Ekonomi Dan Bisnis Islam, 3(1), 36-50.

Putra, R. R., Syifadhiya, S., Widyastiti, S. A., \& Pambuko, Z. B. (2018). Analisis Produktivitas Perbankan Syariah di Indonesia Dalam Mengelola Dana Sosial. Jurnal Ekonomi Syariah Indonesia, 8(1), 74 80.

Pyeman, J., Hasan, H., \& Ahmad, I. (2016). Modernizing Waqf Performance Evaluation By Waqf Management Efficiency Index. Asia-Pacific Management Accounting Journal, 11(2), 1-7.

Qayyum, A., \& Riaz, K. (2012). Macroeconomic crisis and productivity changes in banking sector: Evidence from an emerging economy. World Applied Sciences Journal, 18(12), 1718-1726. https://doi. org/10.5829/idosi.wasj.2012.18.12.2171

Rahman, M. A. (2015). Comparative Study on the Efficiency of Bangladeshi Conventional and Islamic Life Insurance Industry: A Non-Parametric Approach. Asian Business Review, 3(4), 88. https:// doi.org/10.18034/abr.v3i4.284

Rahman, M. M. (2011). Non-Parametric Approach To Model the Branch-Wise Efficiency of Islami Bank Bangladesh Limited (Ibbl): an 
Empirical Study. IIUM Journal of Economics and Management, 19(2), 137-168.

Ramanathan, R. (2007). Performance of banks in countries of the gulf cooperation council. International Journal of Productivity and Performance Management, 56(2), 137-154. https://doi. org/10.1108/17410400710722635

Ramli, N. A., Kamarudin, F., \& Mohamad Anwar, N. A. (2017). Do Citizens' Right Influence The Productivity Of Domestic And Foreign Islamic Banks? Empirical Evidence From Indonesia And Malaysia. E-PROCEEDING OF THE 6TH INTERNATIONAL CONFERENCE ON SOCIAL SCIENCES RESEARCH 2017, 86103.

Rana, S., Mia, A., Ismail, I. B., Nazari, M., \& Ismail, B. (2019). Evaluating Productivity of Microfinance Institutions Evidence from Palestine and Jordan. The Journal of Development Practice, 5, 1-11.

Rani, L. N., Widiastuti, T., \& Rusydiana, A. S. (2017). Comparative Analysis of Islamic Bank's Productivity and Conventional Bank's in Indonesia Period 2008-2016. 1st International Conference on Islamic Economics, Business, and Philanthropy (ICIEBP 2017), 118-123. https://doi.org/10.5220/0007077901180123

Rashid, A., \& Rehman, Z. ur. (2016). Measurement and Decomposition of Productivity Change in Banking: Islamic and Conventional Banks in Pakistan. Journal of Islamic Business and Management, 6(2), 55-75.

Rashidah, A. R., \& Faisal, D. (2015). Efficiency, productivity and Islamic banks: an application of DEA and Malmquist index. Humanomics, 31(3), 118-131. https://doi.org/10.1108/H-04-2014-0037

Rebelo, J., \& Mendes, V. (2000). Malmquist indices of productivity change in portuguese banking: The deregulation period. International Advances in Economic Research, 6(3), 531-543. https://doi. org/10.1007/BF02294970 
Rodoni, A., Salim, M. A., Amalia, E., \& Rakhmadi, R. S. (2017). Comparing Efficiency and Productivity in Islamic Banking: Case Study Indonesia, Malaysia and Pakistan. Al-Iqtishad: Journal of Islamic Economics, 9(2), 227-242. https://doi.org/10.15408/aiq.v9i2.5153

Rustyani, S., \& Rosyidi, S. (2018). Measurement of Efficiency and Productivity of Zakat Institutions in Indonesia using Data Envelopment Analysis and the Malmquist Productivity Index. International Journal of Zakat, 3(3), 69-82. Retrieved from https:// ijazbaznas.com/index.php/journal/article/view/98

Rusydiana, A. S. (2018a). Indeks Malmquist untuk Pengukuran Efisiensi dan Produktivitas Bank Syariah di Indonesia. Jurnal Ekonomi Pembangunan, 26(1), 47-58. https://doi.org/10.14203/ jep.26.1.2018.47-58

Rusydiana, A. S. (2018b). Perubahan Teknologi dan Efisiensi pada Organisasi Pengelola Zakat di Indonesia. Jurnal Liquidity, 7(2), 124136. https://doi.org/10.32546/lq.v7i2.218

Rusydiana, A.S. \& Widiastuti, T. (2018). Technological and Efficiency Change on Zakat Organization: Evidence in Indonesia. International Conference of Zakat 2018, 1-11. Retrieved from https://www. iconzbaznas.com/submission/index.php/proceedings/article/ view/113/60

Rusydiana, A. S., \& Laila, N. (2019). Efisiensi dan produktivitas industri perbankan pada sistem moneter ganda di Indonesia Pendahuluan. Jurnal Siasat Bisnis, 23(1), 50-66. https://doi.org/10.20885/jsb. vol23.iss 1.art5

Rusydiana, Aam S, et al. (2009). Ekonomi Islam Substantif. Jakarta: GP Press.

Saad, N. M., \& Idris, N. E. H. (2011). Efficiency of life insurance Companies in Malaysia and Brunei: A comparative analysis. International Journal of Humanities and Social Science, 1(3), 111-122. Retrieved from http://www.ijhssnet.com/journals/Vol._1_No._3; 
March_2011/17.pdf

Saad, N. M., Majid, M. S. A., Kassim, S., Hamid, Z., \& Yusof, R. M. (2010). A comparative analysis of the performance of conventional and Islamic unit trust companies in Malaysia. International Journal of Managerial Finance, 6(1), 24-47. https://doi.org/10.1108/17439131011015779

Salami, O. L., \& Adeyemi, A. A. (2015). Malaysian islamic banks' efficiency: An intra-bank comparative analysis of islamic windows and full-fledged subsidiaries. International Journal of Business and Society, 16(1), 19-38. https://doi.org/10.33736/ijbs.551.2015

Sanrego, Y. D., \& Rusydiana, A. S. (2017). The Effect of Types and Regulations on the Level of Zakat Management Organization ( OPZ ) Efficiency in Indonesia ( Pengaruh Tipe dan Regulasi Terhadap Tingkat Efisiensi Lembaga Zakat di Indonesia ). Wzf International Conference Proceedings, 65-79.

Siddique, M. A., \& Rahim, M. (2013). Efficiency Analysis of Full-Fledge Islamic Banks and Standalone Islamic Branches of Conventional Banks in Pakistan : A Comparative Study for the Period of 2007 2012. Journal of Islamic Business and Management, 3(2), 129-149. https://doi.org/10.12816/0005000

Sina, A., Sabur, A., \& Rahman, F. (2017). Evaluation of Changes of Total Factor Productivity and Its Components of Islamic Banks in Bangladesh : An Application of Malmquist Index. Australasian Journal of Islamic Finance and Business, 3(2), 81-90.

Soltane Bassem, B. (2014). Total factor productivity change of MENA microfinance institutions: A Malmquist productivity index approach. Economic Modelling, 39, 182-189. https://doi.org/10.1016/j. econmod.2014.02.035

Subana dan Sudrajat. (2005). Dasar-dasar Penelitian Ilmiah. Bandung: Pustaka Setia.

Sufian, F. (2009a). Sources of TFP growth in the Malaysian Islamic banking sector. Service Industries Journal, 29(9), 1273-1291. https:// 
doi.org/10.1080/02642060801911128

Sufian, F. (2009b). Total Factor Productivity Change of the Malaysian Islamic Banking Sector: An Empirical Study. Journal of Islamic Economics, Banking and Finance, 5, 73-88. https://doi.org/10.1016/ S0148-6195(97)10076-5

Sufian, F. (2010). Productivity, technology and efficiency of de Novo Islamic banks: Empirical evidence from Malaysia. Journal of Financial Services Marketing, 15(3), 241-258. https://doi.org/10.1057/fsm.2010.20

Sufian, F., \& Haron, R. (2008). The sources and determinants of productivity growth in the Malaysian Islamic banking sector: a nonstochastic frontier approach. International Journal of Accounting and Finance, 1(2), 193. https://doi.org/10.1504/ijaf.2008.020303

Sufian, F., \& Kamarudin, F. (2014). The impact of ownership structure on bank productivity and efficiency: Evidence from semi-parametric malmquist productivity index. Cogent Economics and Finance, 2(1), 1-27. https://doi.org/10.1080/23322039.2014.932700

Sugiyono. (2008). Metode Penelitian Kuantitatif, Kualitatif, dan R\&D. Bandung: Alfabeta.

Taib, C. A., Ashraf, M. S., \& Razimi, M. S. B. A. (2018). Productivity change in the efficiency of the insurance and takaful industry of Pakistan. Academy of Accounting and Financial Studies Journal, 22(Specialissue), 1-11.

Usman, N., Andriyani, L., \& Pambuko, Z. B. (2019). Productivity of Islamic Banks in Indonesia: Social Funds versus Financial Funds. The Journal of Asian Finance, Economics and Business, 6(3), 115-122. https://doi.org/10.13106/jafeb.2019.vol6.no3.115

Viverita, Brown, K., \& Skully, M. (2007). Efficiency analysis of Islamic banks in Africa , Asia and the Middle East. Review Islamic Economics, 11, 5-16. https://doi.org/10.2307/25675986

Wahab, N. A., \& Rahman, A. R. A. (2012). Productivity growth of zakat institutions in Malaysia: An application of data envelopment 
analysis. Studies in Economics and Finance, 29(3), 197-210. https:// doi.org/10.1108/10867371211246876

Wahab, N. A., \& Rahman, A. R. A. (2013). Determinants of efficiency of zakat institutions in Malaysia: A non-parametric approach. Asian Journal of Business and Accounting, 6(2), 33-64.

Wahid, M. A., \& Harun, M. S. (2019). Productivity of Islamic banks in Malaysia during the pre and post global financial crisis. E-Proceeding of the International Conference on Economic, Entrepreneurship and Management 2019, 22-24.

Wijaya, T. (2013). Metodologi Penelitian Ekonomi dan Bisnis Teori dan Praktek. Yogyakarta: Graha Ilmu.

Yaumidin, U. K. (2007). Efficiency in Islamic Banking: a Non-Parametric Approach. Buletin Ekonomi Moneter Dan Perbankan, 9(4), 23-54. https://doi.org/10.21098/bemp.v9i4.213

Yildirim, I. (2015). Financial efficiency analysis in Islamic banks:Turkey and Malaysia Models. Pressacademia, 2(3), 289-289. https://doi. org/10.17261/pressacademia.2015312956

Yildirim, İ. (2017). Financial Efficiency Analysis Of Islamic Banks In The Qismut Countries. Journal of Islamic Economics and Finance, 3(2), 187-216. 


\section{Appendix}

Appendix 1. MPI Research Publications on Islamic Economics and Finance

\begin{tabular}{|l|l|c|}
\hline No & \multicolumn{1}{|c|}{ Type of Publication } & $\begin{array}{c}\text { Number of } \\
\text { Paper }\end{array}$ \\
\hline & \multicolumn{1}{|c|}{ JOURNAL } & \\
\hline $\mathbf{1}$ & $\begin{array}{l}\text { International Journal of Islamic and Middle } \\
\text { Eastern Finance and Management }\end{array}$ & 3 \\
\hline $\mathbf{2}$ & Journal of Islamic Banking and Finance & 2 \\
\hline $\mathbf{3}$ & Service Industries Journal & 2 \\
\hline $\mathbf{4}$ & Applied Economics & 2 \\
\hline $\mathbf{5}$ & Jurnal Ekonomi Pembangunan & 2 \\
\hline $\mathbf{6}$ & $\begin{array}{l}\text { International Journal of Productivity and } \\
\text { Performance Management }\end{array}$ & 2 \\
\hline $\mathbf{7}$ & Economic Modelling & 2 \\
\hline $\mathbf{8}$ & Education and Humanities Research & 2 \\
\hline $\mathbf{9}$ & Review of Islamic Economics & 2 \\
\hline $\mathbf{1 0}$ & Islamic Economic Studies & 2 \\
\hline $\mathbf{1 1}$ & International Journal of Business and Society & 2 \\
\hline $\mathbf{1 2}$ & Humanomics & 2 \\
\hline $\mathbf{1 3}$ & Journal of Asian Finance, Economics and Business & 2 \\
\hline $\mathbf{1 4}$ & Jurnal Ekonomi Syariah Indonesia & 1 \\
\hline $\mathbf{1 5}$ & $\begin{array}{l}\text { Journal of Islamic Economics, Banking and } \\
\text { Finance }\end{array}$ & 2 \\
\hline $\mathbf{1 6}$ & Journal of Islamic Business and Management & 2 \\
\hline $\mathbf{1 7}$ & $\begin{array}{l}\text { Academy of Accounting and Financial Studies } \\
\text { Journal }\end{array}$ & 2 \\
\hline $\mathbf{1 8}$ & Al-Iqtishad: Journal of Islamic Economics & 2 \\
\hline $\mathbf{1 9}$ & American Journal of Economics & 2 \\
\hline $\mathbf{2 0}$ & Applied Financial Economics & 2 \\
\hline & & \multicolumn{1}{|c|}{. } \\
\hline
\end{tabular}




\begin{tabular}{|c|c|c|}
\hline 21 & $\begin{array}{l}\text { Asian Academy of Management Journal of } \\
\text { Accounting and Finance }\end{array}$ & 1 \\
\hline 22 & Asian Business Review & 1 \\
\hline 23 & Asian Journal of Business and Accounting & 1 \\
\hline 24 & Asia-Pacific Management Accounting Journal & 1 \\
\hline 25 & $\begin{array}{l}\text { Australasian Journal of Islamic Finance and } \\
\text { Business }\end{array}$ & 1 \\
\hline 26 & BDDK Bankacilık ve Finansal Piyasalar & 1 \\
\hline 27 & Buletin Ekonomi Moneter Dan Perbankan & 1 \\
\hline 28 & Cogent Economics and Finance & 1 \\
\hline 29 & Eurasian Business Review & 1 \\
\hline 30 & Gadjah Mada International Journal of Business & 1 \\
\hline 31 & Global Business Review & 1 \\
\hline 32 & IIUM Journal of Economics and Management & 1 \\
\hline 33 & International Advances in Economic Research & 1 \\
\hline 34 & International Journal of Accounting and Finance & 1 \\
\hline 35 & International Journal of Bank Marketing & 1 \\
\hline 36 & International Journal of Business & 1 \\
\hline 37 & $\begin{array}{l}\text { International Journal of Economics and Financial } \\
\text { Issues }\end{array}$ & 1 \\
\hline 38 & $\begin{array}{l}\text { International Journal of Empirical Finance } \\
\text { Information }\end{array}$ & 1 \\
\hline 39 & $\begin{array}{l}\text { Internasional Journal of Financial Economics and } \\
\text { Econometrics }\end{array}$ & 1 \\
\hline 40 & $\begin{array}{l}\text { International Journal of Financial Management } \\
\text { and Economics }\end{array}$ & 1 \\
\hline 41 & International Journal of Hospitality Management & 1 \\
\hline 42 & $\begin{array}{l}\text { International Journal of Humanities and Social } \\
\text { Science }\end{array}$ & 1 \\
\hline 43 & International Journal of Managerial Finance & 1 \\
\hline 44 & $\begin{array}{l}\text { International Journal of Research in Business and } \\
\text { Social Science }\end{array}$ & 1 \\
\hline
\end{tabular}




\begin{tabular}{|c|c|c|}
\hline 45 & International Journal of Zakat & 1 \\
\hline 46 & IOSR Journal of Business and Management & 1 \\
\hline 47 & Islamic Finance: Performance and Efficiency & 1 \\
\hline 48 & Islamic Management and Business & 1 \\
\hline 49 & Journal of Asian Development Studies & 1 \\
\hline 50 & $\begin{array}{l}\text { Journal of Emerging Economies and Islamic } \\
\text { Research }\end{array}$ & 1 \\
\hline 51 & Journal of Financial Services Marketing & 1 \\
\hline 52 & Journal of Islamic Economics and Finance & 1 \\
\hline 53 & Journal of Islamic Finance and Business & 1 \\
\hline 54 & $\begin{array}{l}\text { Journal of King Abdulaziz University, Islamic } \\
\text { Economics }\end{array}$ & 1 \\
\hline 55 & Journal of Risk Finance & 1 \\
\hline 56 & Journal of Technology Management & 1 \\
\hline 57 & Journal of The Malaysian Institute of Planners & 1 \\
\hline 58 & Jurnal Bisnis Dan Manajemen & 1 \\
\hline 59 & Jurnal Keuangan dan Perbankan & 1 \\
\hline 60 & Jurnal Liquidity & 1 \\
\hline 61 & Jurnal Siasat Bisnis & 1 \\
\hline 62 & Jurnal Studi Ekonomi Dan Bisnis Islam & 1 \\
\hline 63 & Management Studies and Economic Systems & 1 \\
\hline 64 & Middle Eastern Finance and Economics & 1 \\
\hline 65 & Panoeconomicus & 1 \\
\hline 66 & Pressacademia & 1 \\
\hline 67 & Research Journal of Finance and Accounting & 1 \\
\hline 68 & Review of Economics and Development Studies & 1 \\
\hline 69 & Social and Management Research Journal & 1 \\
\hline 70 & Studies in Economics and Finance & 1 \\
\hline 71 & $\begin{array}{l}\text { The Central European Review of Economics and } \\
\text { Management }\end{array}$ & 1 \\
\hline 72 & The Journal of Applied Business Research & 1 \\
\hline
\end{tabular}




\begin{tabular}{|l|l|c|}
\hline $\mathbf{7 3}$ & The Journal of Development Practice & 1 \\
\hline $\mathbf{7 4}$ & The Lahore Journal of Economics & 1 \\
\hline $\mathbf{7 5}$ & World Applied Sciences Journal & 1 \\
\hline & \multicolumn{1}{|c|}{ CONFERENCE } & 2 \\
\hline $\mathbf{1}$ & $\begin{array}{l}\text { 1st International Conference on Islamic } \\
\text { Economics, Business, and Philanthropy }\end{array}$ & 1 \\
\hline $\mathbf{2}$ & Prosiding Perkem & 1 \\
\hline $\mathbf{3}$ & 11th Internasional Academic Conference & 1 \\
\hline $\mathbf{4}$ & International Conference of Zakat 2018 & 1 \\
\hline $\mathbf{5}$ & $\begin{array}{l}\text { 13th International Conference on Data } \\
\text { Envelopment Analysis }\end{array}$ & 1 \\
\hline $\mathbf{6}$ & $\begin{array}{l}\text { Internasional Conference on Social Science Studies } \\
\text { (ICSS 2018) }\end{array}$ & 1 \\
\hline $\mathbf{7}$ & $\begin{array}{l}\text { The 6th International Conference On Social } \\
\text { Sciences Research 2017 }\end{array}$ & 1 \\
\hline $\mathbf{8}$ & $\begin{array}{l}\text { World Zakat Forum International Conference } \\
\text { Proceedings }\end{array}$ & $\begin{array}{l}\text { International Conference on Economic, } \\
\text { Entrepreneurship \& Management 2019 }\end{array}$ \\
\hline $\mathbf{9}$ & Working paper & 1 \\
\hline & Total & 1 \\
\hline & & 1 \\
\hline $\mathbf{1 0}$ & \\
\hline
\end{tabular}


132 Aam Slamet Rusydiana, Lina Marlina, Lina Nugraha Rani

Vol. 4 No. 1, January - April 2019 


\section{Shirkah Author Guidelines}

Shirkab currently offers two routes to submit manuscripts. We highly recommend to submit the articles which are made using OJS (Open Journal System). Feel free register as author soon through visiting http://shirkah. or.id/index.php/home/user/register. The authors may directly send their manuscripts, along with their resume, to shirkahiainsurakarta@gmail. com. Please prepare your manuscripts, using following guidelines:

1. Manuscript must be written in English. Submitted articles should not have been published or be under review for publication with another journal.

2. Manuscript's length is about $15-20$ pages, typed in one-half spaced on A4-paper size.

3. Manuscript must include an $150-200$ word abstract and keywords.

4. Manuscript must be arranged as follows: Title, Name of Author, E-mail address, Abstract, Keywords, Introduction (including method if any), Discussion, Conclusion, References.

5. Manuscript's titles not more than ten words.

6. Manuscript must be submitted in Microsoft Word or RTF.

7. Arabic words should be transliterated according to the style of International Journal of Middle Eastern Studies.

8. Manuscript references are preferably derived from the up-to-date references.

9. The author's resume should be submitted separately, consisting of at least full name, institutional address, phone number, areas of studies, and recent publications (if any).

10. Shirkab use APA Style 6th edition (2010) as reference format writing. We suggest the use of a reference manager software such as Mendeley, Zotero, and Endnote at templating the citation style. APA Style to be used is as follows: 


\section{Book with single author}

Swann, G. M. Peter. (2014). The Economics of Innovation an Introduction. Cheltenhum \& Northampton: Edward Elgar.

in-text citation: (Swann, 2014)

\section{Articles in reference books}

Alatas, S. F. (2006). Islam and the Science of Economics in Abu Rabi', I.M. The Blackwell Companion to Contemporary Islamic Thought. USA: Willey-Blackwell (pp. 587-606).

in text citation: (Alatas, 2006)

\section{E-Book}

Hackett, Rosalind (2007). "Religous Dimentions of War and Peace: Introduction." Dalam Gerrie ter Haar dan Yoshio Tsuruoka (Ed.), Religion and Society: An Agenda for the 21st Century (h. 3-6). Retrieved from http:// brill.nl.

in text citation: (Hackett, 2006)

\section{Master's thesis, from a commercial database}

McNieI, D. S. (2006). Meaning through narrative: A personal narrative discussing growing up with an alcoholic mother (Master's thesis). Available from ProQuest Dissertations and Theses database. (UMI No. 1434728)

in text citation: (Mc Niel, 2006)

\section{Doctoral dissertation, from an institutional database}

Adams, R. J. (1973). Building a foundation for evaluation of instruction in higher education and continuing education (Doctoral dissertation). Retrieved from http://www.ohiolink.edu/etd/

in text citation: (Adams, 1973) 


\section{Doctoral dissertation, from the web}

Bruckman, A. (1997). MOOSE Crossing: Construction, community, and learning in a networked virtual world for kids (Doctoral dissertation, Massachusetts Institute of Technology). Retrieved from http:/www-static. cc.gatech.edu/--asb/thesis/

in text citation: (Bruckman, 1997)

\section{Journal article with No DOI}

Bourkhis, K., and Nabi, M. S. (2013). Islamic and conventional banks' soundness during the 2007-2008 financial crisis. Journal Metrics, 22(2), 68-77.

in-text citation: (Bourkhis \& Nabi, 2013).

\section{Journal article with DOI}

Ichwan, M. (2012). The Local Politics Of Orthodoxy: The Majelis Ulama Indonesia in the Post-New Order Banten. Journal Of Indonesian Islam, 6(1), 166-194. doi:http://dx.doi.org/10.15642/JIIS.2012.6.1.166-194

In text citation : (Ichwan, 2012)

\section{Abstract as citation}

Hasan, N. (2012). Islamist Party, Electoral Politics And Da'wah Mobilization Among Youth : The Prosperous Justice Party (PKS) in Indonesia. Journal of Indonesian Islam, 6(1), 17-47. Abstract from http://jiis.uinsby. ac.id/index.php/jiis/article/view/97

in text citation : (Hasan, 2012)

\section{Mass media article}

Sahal, Akhmad (2014, March 2). Kiai Sahal dan Realisme Fikih.Tempo Magazine, p. 120.

in text citation : (Sahal, 2014) 


\section{Research report}

Fisher, B. S., Cullen, F. T., \& Turner, M. G. (2000). The Sexual Victimization of College Women. Research Report.

in text citation : (Fisher, Cullen, Turner, 2000)

\section{Monograph}

Routray, Bibhu Prasad (2013), National Security Decision-Making in India (RSIS Monograph No. 27). Singapura: Rajaratnam School of International Studies.

in text citation : (Routray, 2013)

\section{Proceeding article}

Sudibyakto, Hizbaron, D.R., \& Jati, R (Ed.) (2009), Proceeding International Seminar Disaster Theory, Research and Policy. International seminar held by Sekolah Pascasarjana, Universitas Gajahmada, Yogyakarta, 8-9 Desember 2009.

in text citation : (sudibyakto and Jati, 2009)

\section{Paper conference/seminar/symposium}

Janutama, Herman Sinung (2011). "Kraton dan Hubungan Antar Agama." Paper presented in Seminar Kraton dan Panatagama held by Center for the Study of Islam and Social Transformation (CISForm), Yogyakarta, 17 November.

in text citation :(Janutama, 2011)

\section{Online article in web}

Shiva, (2006, February). Bioethics: A Third World Issue. Native-web. Diperoleh dari http://www.nativeweb.org/ pages/legal/shiva.html

in text citation : (Shiva, 2006) 


\section{Online research report}

Kessy, S. S. A., \& Urio, F M. (2006). The contribution of microfinance institutions to poverty reduction in Tanzania (Research Report No. 06.3). Retrieved from Research on Poverty Alleviation website: http://www.repoa.or.tz/documents_storage/Publications/Reports/06.3_Kessy_and_ Urio.pcif

in text citation : (kessy and urion, 2006)

\section{Holy book}

Qur an, $2(25)$

In text citation : (Q. al-Baqarah 2:25).

\section{Encyclopaedia}

Graycar, Adam (1992). Social Welfare Policy. Dalam Mary Hawkesworth dan Maurice Kogan (Ed.), Encyclopedia of Government and Politics (Vol. 1). London: Routledge.

in text citation : (Graycar, 1992)

\section{Interview}

Sultan Hamengkubuwono X (interview, 2011, April 19)

in text citation: (Hamengkubuwono, 2011)

\section{Documentary film}

Steijlen, Fridus (2008). A Day in the Life of Indonesia [documentary film, 58 minutes]. Leiden: KITLV Press.

in text citation : (Steijlen, 2008) 
Vol. 4 No. 1, January - April 2019 